\title{
Conceptualizing Fairness in Classroom Assessment: Exploring the Value of Organizational Justice Theory
}

\author{
Amirhossein Rasooli ${ }^{\mathrm{a}}$, Hamed Zandi ${ }^{\mathrm{b}}$, \& Christopher DeLuca ${ }^{\mathrm{a}}$ \\ ${ }^{a}$ Faculty of Education, Queen's University, Kingston, Canada \\ ${ }^{b}$ Institute for Advanced Studies in Basic Sciences, Iran
}

Full Citation:

Rasooli, A., Zandi, H., \& DeLuca, C. (2019). Conceptualizing Fairness in Classroom Assessment: Exploring the Value of Organizational Justice Theory. Assessment in Education: Principles, Policy \& Practice.

https://doi.org/10.1080/0969594X.2019.1593105
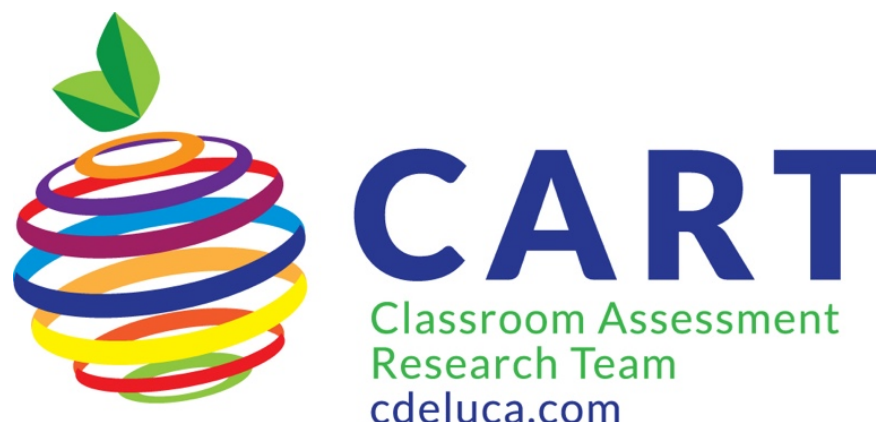

Classroom Assessment Research Team cdeluca.com

\author{
Contact: \\ Christopher DeLuca \\ cdeluca@queensu.ca \\ @ChrisDeLuca20
}




\begin{abstract}
Fairness has recently moved into the spotlight as a core foundation of classroom assessment (CA). However, despite its significance for high quality CA, fairness definitions and theories have been limited in the literature. Driven by the critiques directed at the 'inadequacy' and 'fuzziness' around CA fairness and recommendations to conceptualize fairness particularly for CA contexts, this paper aims to provide an explicit definition of CA fairness. Specifically, this paper brings together current scholarship in organizational justice theory and recent findings from the CA fairness literature to offer a more thorough conceptualization. This conceptualization not only presents a distinction between justice and fairness, but also provides a novel discussion of the relationship between justice and fairness with consideration for potential effects on students' learning. The paper concludes with an agenda for further research on CA fairness.
\end{abstract}

Keywords: Fairness, Justice, Classroom Assessment, Conceptualization, Organizational Justice Theory 
Fairness is becoming a major area of interest in assessment theory within both large-scale and classroom assessment (CA) contexts. In large-scale contexts, the latest publication of the Standards for Educational and Psychological Testing (2014) allocated a key chapter to the issue of fairness, giving testimony to its prominence as one of the three fundamental concepts in testing, the two others being validity and reliability. CA researchers have also highlighted the importance of fairness in student-based assessments by publishing a separate chapter on the issue of fairness in the Sage Handbook of Research on Classroom Assessment (2013) and in the Principles for Fair Student Assessment Practices for Education in Canada (Rogers, 1996a, 1996b). These key chapters sit alongside other recent writings in the field to signal increased attention to fairness as a renewed and important construct for $21^{\text {st }}$ century assessment (Cowie, 2015; DeLuca, LaPointe-McEwan, \& Luhanga, 2016; Gipps \& Stobart, 2009; Scott, Webber, Lupart, Aitken, \& Scott, 2014; Tierney, 2016).

Despite the endorsement of fairness as a fundamental pillar of high quality assessment, there has been surprisingly limited efforts at defining and theorizing fairness in both contexts (Nisbet, 2017; Tierney, 2013, 2014). Reviewing the two handbooks on the conceptualization of fairness in the large-scale context, Nisbet $(2017$, p. 6) concluded that there has been "a disappointing lack of conceptual analysis of fairness in either volume”, with most authors having shied away from defining fairness. Similarly, Tierney (2013) after reviewing standards of practice, conceptual literature, and empirical studies in the CA context, concluded that the concept of fairness lacks a clear definition in the literature. Furthermore, Tierney (2013) underscored that, to date, CA fairness has largely been examined through conventional theories practiced in measurement literature, with limited understanding of the dynamics that $\mathrm{CA}$ practices bring to the learning environment. In a follow-up study, Tierney (2014) explicitly 
called for additional conceptualizations of CA fairness from perspectives outside assessment and measurement areas to expand understandings of CA fairness. It seems that the current theories of CA fairness are limited in their integration of perspectives beyond measurement or assessment domains (Authors).

In response to Tierney's call, the overarching purpose of this paper is to explore a new perspective on CA fairness by building on organizational justice theory, which has been documented to be a productive theory for conceptualizing fairness in other educational domains (Chory-Assad, 2002; Grace, 2017). Accordingly, this paper aims to bring together current scholarship in organizational justice theory and recent findings from CA fairness literature to offer a more thorough conceptualization and definition of fairness for CA contexts. This conceptualization not only presents a distinction between justice and fairness, but also provides a novel discussion of the relationship between justice and fairness with consideration for potential effects on students' classroom learning.

To that end, this paper is organized into the following four parts. Section I provides a sociocultural conceptualization of CA that signals our approach to defining assessment and fairness in this study. Section II identifies relevant definitions and theories of fairness in the CA assessment literature. Section III reviews the theorization, definition, and theoretical model of fairness provided in organizational justice theory. Finally, section IV proposes a conceptualization for CA fairness based on organizational justice theory and CA literature. Based on this conceptualization, we conclude the paper with a research agenda to guide future studies in CA fairness research.

\section{Section I. Sociocultural definition of CA}


In this study, we conceptualize CA as a process whereby teachers and students collaborate in selecting, gathering, analyzing, and using evidence of student learning for various reasons, including defining the learning targets, monitoring of student progress toward achieving the learning targets, providing feedback to teachers, students, and parents to gauge where students are in relation to the learning targets and what the next steps are, and assigning grades (Andrade, 2013; McMillan, 2013). In this conceptualization, teachers and students actively employ strategies to successfully achieve learning targets through teacher, peer, and self-directed assessments and feedback. These assessments not only formatively stimulate and motivate content learning and self-regulation skills, but also help in summative appraisals of learning outcomes. Altogether, this conceptualization of CA is grounded in a socio-cultural milieu where assessment transpires in the dynamic intersections of classroom management, learning culture, pedagogy, curriculum, and in recognition of the diversity of students and teachers within classroom environment (Brookhart, 2004; Cowie \& Bell, 1999; Shepard, 2001). Given this conceptualization of assessment, we follow others in recognizing that assessment is not homogenous across contexts but that different contexts will lead to different ways of enacting assessment (Klenowski, 2009). Similarly, our conceptualization of CA fairness assumes that fairness is a situational construct, shaped by contextual variations.

\section{Section II. Review of the Current Definitions and Theories of CA Fairness}

\section{Fairness Definitions}

A recent systematic review of the literature of CA fairness (Authors) identified empirical and non-empirical literature related to fairness in the CA context. Overall, 50 studies were identified in the systematic search that directly related to CA fairness (see Appendix for a summary of studies). For this paper, these 50 studies were reviewed for their explicit articulation 
of a definition for fairness. General definitions rather than definitions associated with particular assessment practices (e.g., feedback, grades) were reviewed in this study. Further, only theoretical definitions of fairness were included rather than the procedural definitions, which aim to enact specific strategies and principles to enhance fair practices (see Suskie, 2002; Volante, 2006 in Appendix for examples of a procedural definition).

Our results for general and theoretical definitions of fairness are reported in Table 1. Alarmingly, only 8 of the 50 studies explicitly defined fairness, (five were theoretical and three empirical), suggesting that most of the empirical studies have interpreted their research findings without an explicit definition of fairness.

INSERT TABLE 1 HERE

The various definitions presented in Table 1 contain several keywords often associated or used interchangeably with fairness including equity, justice, equality, ethics, equitable, and nondiscriminatory. For example, some researchers (Gipps \& Stobart, 2009; Klenowski, 2009) have recognized equity and fairness as a qualitative concern for what is just. This finding confirms Tierney's (2013) conclusion that there is significant 'fuzziness' and 'circularity' around the definition of fairness in the CA literature as researchers use multiple terminologies such as justice, bias, ethics, and objectivity interchangeably.

Further analysis of the definitions indicate that although researchers have used various metaphors and terminology to explain fairness concepts, they have provided little further explanation to help readers interpret or distinguish them. For example, three studies (Ortiz, 2002; Poehner, 2011; Siegel, 2014) have employed three terms - nondiscriminatory assessment, fairness, and equitable assessment - to refer to the equity principle, which argues for a distribution of outcomes based on students' needs, merit, and cultural and language background. Despite this underlying similarity, there lies certain variations in their interpretation of equity. 
Poehner (2011) defines equity as the distribution of teaching outcomes (or learning opportunities) based on the Vygotskiyan notion of zone of proximal development, while Ortiz (2002) and Siegel (2014) characterize equity as distributing assessment opportunities based on students' needs and cultural and language background. In other words, Poehner (2011) considers equity as an opportunity to learn in the cycles of teaching, assessment, and learning, while Ortiz (2002) and Siegel (2014) view equity as opportunity to demonstrate learning in evaluation and assessment contexts based on students' backgrounds and needs.

Gipps and Stobart (2009) characterize equity similarly to Poehner's (2011) opportunity to learn; however, they extend his conception beyond learning opportunities in the classroom to incorporate students' opportunities to enjoy similar facilities, resources, and materials prior to assessment. Moreover, they subsume equality, which can be calculated through quantitative approaches (e.g., DIF) under equity, which emphasizes equality of opportunities beyond testing contexts. Inspired by Gipps and Stobart (2009), Klenowski $(2011,2014)$ also considers equity as a sociocultural issue because it takes into account equality of opportunities beyond and prior to assessment (i.e., resources, material, and facilities) rather than mere equality on the testing contexts.

The last two studies (Green, Johnson, Kim, \& Pope, 2007; Liu, Johnson, \& Fan, 2016) focus on the metaphor of ethics as a basis for fairness. According to Liu et al. (2016) "in the classroom, ethics serves to ensure the quality and fairness of assessment" (p. 57). These two studies define ethical behavior generally as "acting based on one's judgment of an obligation" (Greet et al., 2007, p. 1000). This general definition refers to teachers' judgment of ethical issues in assessment in these two studies as they attempt to decipher the extent teachers agree with ethical and fair principles in CA. 
In conclusion, the review of fairness definitions suggests that (a) few CA studies have attempted to explicitly define fairness; (b) fairness has been equivocally defined and fuzziness abounds in the distinctions between fairness and related keywords; and (c) CA researchers seem to be predominantly concerned with assessment dimension of fairness, with few studies reaching beyond the assessment domain to define fairness for CA contexts. We interpret these findings as suggesting that fairness is an evolving and multidimensional phenomenon. Moreover, we recognize that fairness as related to assessment literature has largely been theorized from psychometric and large-scale traditions, rather than conceptualized from a classroom assessment perspective. In part, this conceptualization is due to the fact that classroom assessment theory is a relatively new field compared to the longer psychometric tradition. As such, we encourage through this paper a reconceptualization of fairness for CA contexts. While there is not necessarily a need for a unified and singular definition of fairness, there is a need to map the discursive terrain and to explicitly use definitions with intention and purpose. Hence, as fairness evolves there is a continued need, in our view, to press upon the definitions provided, to explain and expand them by reaching beyond assessment and measurement domains to provide a more comprehensive conceptualization of the multiple dimensions of CA fairness.

\section{CA Fairness Theories}

The same methodology and 50 studies were used to identify articulated theories of CA fairness. Table 2 demonstrates that only 10 of the 50 studies explicitly reported their theoretical framework of fairness.

INSERT TABLE 2 HERE

The analysis of the 10 studies suggests that five studies employed principles of equity, equality, and need as their theory of CA fairness (Alm \& Colnerud, 2015; Cowie, 2015; Lantolf \& Poehner, 2013; Murillo \& Hidalgo, 2017; Poehner, 2011). These three principles describe 
fairness based on whether or not outcomes in the classroom (e.g., grades, feedback, and opportunity to demonstrate learning) should be distributed based on merit, equality, or need. Although these principles can somewhat account for fairness in relation to distribution of outcomes such as grades and feedback, they may fail to thoroughly account for other aspects of fairness such as transparency and respectfulness that have been documented to play a role in the fairness of CA practices (Authors; Tierney, 2014).

Further, three studies (Green et al., 2007; Liu et al., 2016; Pope, Green, Johnson, \& Mitchell, 2009) adopted do no harm and avoid score pollution principles to support their theoretical understanding of fairness. Do no harm mandates that assessment should avoid harming students while avoid score pollution implies teachers should exclude constructirrelevant factors (i.e., irrelevant to achievement) from assessments. It is worth noting that do no harm and avoid score pollution are prescriptive theories. Contrary to the descriptive theories that attempt to describe individuals' conceptions of fairness (without judging if they are true or not), prescriptive theories prescribe what constitutes a fair practice. Prescriptive theories can be beneficial for theorizing ethics and fairness in CA when some consensus exist on what constitutes (un)fair practices among stakeholders. As little is known about the ethical and fairness conceptions of diverse stakeholders, these studies (Green, et al. 2007; Pope et al., 2009; Liu, et al. 2016) developed their instrument based on the ethical and fairness principles in standards [The Joint Committee on Standards for Educational Evaluation (JCSEE), 2003] and guidelines that reflect the ethical and fair values of researchers as the stakeholders who develop them. Furthermore, these studies aimed to only report on the extent to which teachers agreed or disagreed on an ethical or a fair scenario and avoided judging what practices were actually 
(un)ethical and (un)fair based on their theory. A next step would be to establish a fairness dialogue by exploring stakeholders' variable application of prescriptive theories.

Another study, Tierney (2014), adopted Aristotle's phronesis to inductively understand teachers' thinking about CA fairness as a way to reframe CA fairness. Phronesis refers to the ability "to judge correctly, all things considered, the best action to perform in any given situation"' (Warne, as cited in Tierney, 2014, p. 56). In instructional contexts, Sabbagh (2009) argues that phronesis "requires reflective thinking that enables teachers to judge and behave prudently" (p. 667). Accordingly teachers' phronesis is influenced by dimensions such as theoretical, technical, and moral knowledge, experience, and personal characteristics. Building on the moral dimension, Tierney explored 6 teachers' CA fairness conception (i.e. phronesis) to re-conceptualize CA fairness. It seems that Tierney's main motivation in using phronesis was to provide evidence about why teachers' thinking can be explored to provide a reframed theory of CA fairness; however, it appears unclear how this theory, due to its general conceptualization, has guided her practice in conducting thematic analyses and interpreting teachers' views about CA fairness beyond what an inductive analysis can offer.

The $10^{\text {th }}$ study by Lizzio and Wilson (2008) explored students' perceptions on dimensions of effective feedback. Driven by the conceptualizations of fairness in organizational justice theory, they identified fairness as one of the key dimensions of effective feedback. It appears that organizational justice theory provides a useful platform to conceptualize CA fairness because similar to employees, students consider the distribution of outcomes (e.g., grades), the procedures of outcome distributions (e.g., procedure of feedback provision), the interpersonal relationships (teacher-student, and peer relations), and the communication of information (e.g., truthfulness and justification of grades) in their perceptions of fairness. 
The review of fairness theories suggests that (a) select CA studies have attempted to explicitly frame their study within a theoretical framework of fairness; (b) the current CA fairness theories, which mainly draw on measurement and assessment literature do not fully consider the dynamic and multidimensional nature of CA fairness (Author); and (c) extending to fairness theories beyond measurement and assessment domains, such as organizational justice theory, can augment current understandings of CA fairness by fully engaging the dynamic relationship among multiple dimensions of CA fairness.

\section{Section III. Organizational Justice Theory}

\section{Fairness Inquiry in Organizational Justice Theory}

Fairness is a moral issue with its theoretical roots tracing back to moral philosophy that is comprised of three branches: meta-ethics, normative ethics, and descriptive ethics (Frankena, 1973). Meta-ethics deals with several ontological and epistemological questions such as what fair or unfair means and whether fairness and unfairness actually exist? (Frankena, 1973). Normative ethics prescribes and evaluates (un)ethical acts based on standards or frameworks; fairness in normative ethics, "refers to the extent to which a given action, outcome, or circumstance is in alignment with a certain ethical paradigm" (Hosmer, as cited in Folger \& Cropanzano, 1998, p. xiv; Cropanzano \& Greenberg, 1997). Descriptive ethics describes what individuals consider as (un)ethical without conforming to an evaluation of their ethical values, and it is this branch of ethics to which organizational justice theory belongs.

Organizational justice theory tends to describe justice phenomenologically as "an act is 'just' because someone thinks it is just and responds accordingly. This definition is subjective and socially constructed" (Folger \& Cropanzano, 1998, p. xiv; Cropanzano \& Greenberg, 1997). Educational researchers have extended organizational justice theory to classroom contexts 
(Chroy-Assad, 2002; Kazemi, 2016) and assessment contexts (Lizzio \& Wilson, 2008), arguing that the justice principles prevalent in organizations maintain for classroom contexts in which students and teachers interact through a framework of ethics, justice, and fairness. We also believe that the nature of fairness inquiry in organizational justice theory tends to provide an appropriate platform to conceptualize CA fairness as a socio-cultural issue.

Distributive, Procedural, and Interactional Dimensions of Organizational Justice. The term ‘organizational justice’ was introduced by Greenberg (1987) to tap into employees' proactive and reactive perception of the fairness of outcomes, processes, and interpersonal behavior in the workplace along with their associated affective, cognitive, and behavioral reactions (Greenberg, 2011). By outcomes, processes, and interpersonal behavior, Greenberg (1987) refers to three dimensions of the organizational justice construct: distributive, procedural, and interactional justice.

Distributive justice. Distributive justice refers to the perception of the fairness of outcome distribution (Kazemi \& Törnblom, 2008). Adams's (1965) equity theory-one of the most famous conceptualizations of distributive justice (Greenberg, 2011)—suggests that individuals establish justice first by analyzing their contribution (e.g., work hours and expertise) vis-a-vis their outcome (e.g., salary and grade) and then by comparing their contribution-to-outcome proportion with the contribution-to-outcome proportion of similar others (Kazemi \& Törnblom, 2008). Comparable results entail a justice perception while incomparable results lead to perceptions of injustice (Adams, 1965).

Procedural justice. Although Adams's (1965) equity theory has been influential, it has also attracted criticism; for example, Deutsch (1975) posited that individuals may also perceive fairness in relation to principles of equality and need. Further, Thibaut and Walker (1975) argued 
that equity theory focused only on outcome of fairness whereas individuals also consider the fairness of procedures for outcome distributions (Bobocel \& Gosse, 2015; Byrne \& Cropanzano, 2001). This criticism vitalized a new dimension of organizational justice, namely procedural justice. Building upon Thibaut and Walker, Leventhal (1980) speculated that employees perceive procedural justice if a procedure was implemented consistently across people and across time, avoided personal bias, was based on accurate and adequate information, could be corrected when identified as wrong, considered the concerns of all those involved, and was based on current ethical and moral values.

Interactional justice. Despite the emphasis of distributive and procedural justice on structural aspects of fairness (i.e., what and how outcomes are distributed), Bies and Moag (1986) introduced another addition to the theory - interactional justice - to refer to the social aspect of fairness. Later on, Greenberg (1993) distinguished between interpersonal and informational justice as two facets of interactional justice. Interpersonal justice involves treating individuals with propriety, respect, politeness, and dignity; whereas informational justice is concerned with providing adequate, truthful, and honest information.

In summary, distributive justice is concerned with what outcomes are distributed, procedural justice considers how outcomes are distributed, and interactional justice conceptualizes justice in terms of how individuals are treated (i.e. respect and politeness) and how they are provided with information (i.e. adequacy and truthfulness). Combined, they provide a more comprehensive account of the multidimensional nature of fairness embedded within sociocultural contexts of CA.

\section{Distinction between Fairness and Justice}


The terms 'fairness' and 'justice' have been used interchangeably in the above section to summarize organizational justice theory because these terms have historically been used as 'substitutable' and 'synonymous' terms (Cropanzano, Fortin, \& Kirk, 2015). However, several scholars have recently argued for distinguishing them (Colquitt \& Rodell, 2015; Cropanzano et al., 2015; Goldman \& Cropanzano, 2015; Mikula, 2005).

Three strands of evidence have been argued to distinguish between fairness and justice. The first strand reviews the distinctions between fairness and justice in ancient sources, followed by the second strand discussing the conceptual relationship between these two terms as presented in organizational justice theory. The third strand presents the measurement distinctions between fairness and justice. Drawing on the key perspectives from each of these strands, we are able to gain an understanding of the theoretical and empirical distinctions between fairness and justice.

\section{Fairness and Justice in the Ancient Sources}

Goldman and Cropanzano (2015) reviewed the distinctions made between fairness and justice in the Holy Books, such as the Old Testament and Koran. To illustrate the difference, they provided an example of the Parable of the Vineyard Owner where, one day, the owner of a vineyard recruited laborers to work in the garden at four different times: morning, 12:00, 15:00, and 17:00. In the evening, the owner called all the labors, hired in four different times, and paid all of them equally with a denarius. Those who had worked for longer hours protested while the owner answered: 'I am not being unfair to you, friend. Didn't you agree to work for a denarius? ... I want to give the one who was hired last the same as I gave you. ... Or are you envious because I am generous?” (Matthew 20: 1-16, as cited in Goldman \& Cropanzano, 2015, p. 314).

In this parable, the owner is considered just as he conformed to at least one justice principle (e.g., equality) in the distribution of payments; however, some of the labors perceived 
the owner as unfair. This excerpt indicates that what appears to be just is not necessarily perceived as fair. This observation has led some researchers to distinguish between the meaning of justice and fairness. Thus, justice refers to "adherence to rules of conduct" (i.e. justice principles) while fairness looks at "individuals' moral evaluations of this conduct" (Goldman \& Cropanzano, 2015, p. 313).

\section{Conceptual Difference between Justice and Fairness}

Cropanzano et al. (2015) proposed a simplified model for the process of fairness perception. For this paper, this model serves the purpose of clarifying the causal relationship between justice and fairness as well as the rationale for their distinction. This model is illustrated in Figure 1. In the model, justice is defined as the perceived alignment with principles that reflect appropriateness in a context (Colquitt \& Rodell, 2015). Justice principles associated with each dimension of organizational justice theory (i.e. distributive, procedural, interpersonal, and informational) are included in Table 3. These principles are used as a benchmark by individuals to assess the justice of an event (Cropanzano, et al., 2015). On the other hand, fairness refers to "a global perception of appropriateness. In this formulation, fairness is theoretically 'downstream’ from justice” (Colquitt \& Rodell, 2015, p. 188) and includes a subjective and evaluative judgment of justice principles (Goldman \& Cropanzano, 2015).

\section{INSERT FIGURE 1 HERE}

\section{INSERT TABLE 3 HERE}

The following example explicates the causal relationship between justice and fairness.

When a student wonders if she deserves the grade, she might apply several justice principles to form her perceptions of justice. In this process, the student might compare her grade with her 
effort and contributions (equity principle), examine the extent the teacher has applied the grading criteria consistently (consistency principle), consider the extent she has had voice and control in case of grievances about the grade (voice principle), examine the extent she has been given adequate information about the grading criteria (justification principle), and analyze the extent her grade is justified against her inputs (equity and justification principles).

The student might arrive at a perception of (in)justice by analyzing the extent to which the teacher has adhered to each of the above justice principles. The teacher might be perceived as unjust if he fails to explain the grading criteria, for example. On the contrary, the teacher might be perceived as just if he clearly explains the grading criteria and applies it consistently. Thus, the application of each principle of justice provides an account of the perception of justice. On the other hand, the interplay and combined effect of these distributional (e.g., equity and need), procedural (e.g., accuracy and consistency), and informational (e.g., truthfulness and justification) principles contribute to the student's global perception of grading fairness.

\section{Measurement Distinctions between Fairness and Justice}

Two approaches have been identified in the measurement of fairness and justice: direct versus indirect measurement (Colquitt \& Shaw, 2005). Direct measures assess the evaluation of fairness (Cropanzano, et al., 2015) and include items that refer to the term 'fairness' explicitly in the prompts (e.g., my teacher is fair; the procedure of grading in this class is fair). On the other hand, indirect measures assess the perception of justice and include items that measure justice principles without referring to the word 'fairness'. For example, the item "my teacher treats us respectfully in the classroom" measures the justice principle of respect and the item "I got the grade that I deserved" measures the justice principle of equity. 
As seen in Figure 1, indirect measures are assumed to be causally related to the direct measures. In an attempt to empirically examine this assumption, Ambrose and Schminke (2009) hypothesized that overall fairness mediates the relationship between justice types and outcomes such as job satisfaction, job commitment, and turnover intentions. They found that distributive, procedural, and interactional justice accounted for $33 \%$ of the variance in overall fairness, suggesting that the indirect measures have failed to explain the additional $67 \%$ of variance. Similar findings were found in a meta-analysis conducted by Colquitt, Conlon, Wesson, Porter, and $\mathrm{Ng}$ (2001). They reported that only $47 \%$ of the variance in the procedural fairness was explained by the indirect measures of procedural justice. Building on these findings, Karriker, Williams, and Williams (2017) concluded that fairness and justice might be empirically distinct. To further investigate this hypothesis, Karriker et al. (2017) argued that the direct measures of distributive, procedural, and interpersonal could account for an additional variance in their respective outcome variables such as group commitment, instrumentality, and helping behavior beyond what can be accounted for by the indirect measures. They discovered that only interpersonal fairness predicted helping behavior more significantly than interpersonal justice, while distributive and procedural justice were better predictors for their respective outcomes. Another key implication in Karriker et al.'s (2017) study was that if only an indirect measure is employed to predict perception of fairness, it would fail to account for $21-27 \%$ of the variance as measured solely by a direct measure of fairness. Building on the belief that fairness evaluation is causally driven by justice principles, Karriker et al. (2017) tended to attribute this additional variance, captured solely by direct measures, to the justice principles that had not been included and measured in the indirect measures. 
However, several studies have challenged this idea and demonstrated that justice principles only partially account for the variances in fairness evaluation (Nicklin, Greenbaum, McNall, Folger, \& Williams, 2011; Rodell, Colquitt, \& Baer, 2017). For example, Rodell et al., (2017) examined whether perception of fairness is merely explained by perception of justice or charismatic qualities (i.e. magnetism, passion, energy, and enthusiasm) of an organizational manager also alter the perception of fairness. Their findings defied the established beliefs that perception of fairness is merely driven by perception of justice; rather, they demonstrated that charismatic qualities also predict the evaluation of fairness significantly. Similar findings have also been reported in the literature of classroom fairness in relation to the influence of learning styles (Crosthwaite, Bailey, \& Meeker, 2015) and personality types (Duplaga \& Astani, 2010) on students' perception of fairness. For example, Crosthwaite et al. (2015) detected that students with an individual learning style thought of the fairness of grades for classroom participation as being rather more unfair than students with a project learning style, as the former group tended to work alone due to their personality type. Overall, these findings suggest that fairness and justice can be empirically distinct constructs; nonetheless, more research is needed to study the effect of mediating factors such as learning style and belief in a just world (Peter \& Dalbert, 2010) on the fairness perception.

The reviewed three strands of evidence support the argument that fairness and justice are related but distinct constructs: first, justice has been used in ancient sources to implicate adherence to principles of appropriateness while fairness refers to the global evaluation of these principles. Second, fairness has conceptually and empirically been documented to mediate the relationship between justice and outcome variables (Ambrose \& Schminke, 2009). Third, empirical studies have revealed that (a) justice principles can partially explain the variance in 
fairness evaluation; (b) fairness can individually explain $21-27 \%$ of individuals' perception of fairness; and (c) fairness is not only driven by justice principles, but also can be mediated by other factors (e.g., personality type).

\section{A Theoretical Model in Organizational Justice}

While the simplified model (Figure 1) served properly for clarifying the causal relationship between justice and fairness, a more sophisticated model is presented in Figure 2. This model divides justice principles into four dimensions based on organizational justice theory. Colquitt and Rodell (2015) call these justice dimensions 'faceted justice.' Facet means 'dimension' in their terminology and 'justice' refers to the principles and their associated perception of justice. Beside each of the justice dimensions, the model presents one-to-one fairness counterparts (i.e. distributive, procedural, interpersonal, and informational fairness dimensions). Colquitt and Rodell (2015) term these fairness counterparts 'faceted fairness', which they recognize as distinct from 'overall fairness'. Similar to faceted justice (i.e., justice dimensions), 'faceted fairness' is synonymous with dimensions of fairness, but the term 'fairness' focuses on global evaluation of appropriateness rather than specific justice principles (Colquitt \& Rodell, 2015). Unlike faceted justice and faceted fairness, overall fairness does not take into account the distinctions among dimensions, but it entails a global perception of appropriateness (Colquitt \& Rodell, 2015).

Examining an example from the CA context can help elucidate these distinctions among faceted justice, faceted fairness, and overall fairness. When students are asked to conceptualize the justice of an attendance policy, they might refer to several principles; they might consider whether or not the attendance policy is applied to all students equally (equality principle); they might consider if the teacher gives voice to students to express their ideas about attendance 
policy (voice principle); and they might consider if the teacher explains his decisions in terms of the attendance policy (justification principle). If we construct items that assess each of these justice principles, we are measuring the faceted perception of justice (e.g., the teacher explains his decisions in terms of classroom attendance policy, which only invokes principle of justification). If we wanted to assess faceted fairness, in contrast, we would need to broaden our questioning to examine the totality of experience for each dimension. For example, the item the procedure of classroom attendance policy is fair in this classroom can invoke several principles of procedural justice associated with the classroom attendance domain. Finally, overall fairness can employ items like "the teacher employs a fair classroom attendance policy", which brackets the entire experience of the attendance policy as relevant to the four dimensions of distributive, procedural, interpersonal, and interactional.

The final part of the model (i.e., attitudinal and behavioral responses) completes the last piece of the puzzle of organizational justice theory, arguing that individuals' perception of fairness might bring about positive or negative outcomes (i.e., attitudinal and behavioral response). This relationship between perceptions of fairness and outcomes would help justify persistent findings in educational research demonstrating that classroom fairness is associated with outcomes of students' learning (Chory-Assad, 2002) and motivation (Holmgren \& Bolkan, 2014) while unfairness is associated with students' aggression and hostility (Chory-Assad \& Paulsel, 2004b).

INSERT FIGURE 2 HERE

\section{Section IV. Classroom Assessment Fairness Conceptualization}

In this final section, we bring together our previous analyses to offer a more comprehensive definition and conceptualization of fairness for CA contexts. This conceptualization has identified justice principles inspired by organizational justice theory as 
well as findings from a systematic review of CA fairness (Authors). Further, this

conceptualization considers justice as a distinct but related construct to fairness, with its potential effects on students' learning. Drawing on the definition of fairness proposed in organizational justice theory (Colquitt et al., 2001; Cropanzano et al., 2015; Folger \& Cropanzano, 1998; Greenberg, 1987, 2011), fairness in CA, as perceived by students, is an overall evaluative judgment of the degree to which assessment activities, events, and administrators adhere to the distributive, procedural, and interactional justice principles in the learning ecosystem and that bears affective, cognitive, and behavioral consequences for students' learning.

Table 4 presents the dimensions of our proposed conceptualization of CA fairness. This conceptualization is predicated on previous organizational justice literature and integrates key concepts of fairness as identified within CA contexts. Specifically, four dimensions were identified for CA fairness: classroom distributive justice, classroom procedural justice; and classroom interactional justice, and overall fairness. Classroom distributive justice considers the perception of fairness in relation to distribution of outcomes. Classroom procedural justice refers to the perception of fairness in relation to the classroom procedures. Classroom interactional justice considers how respectfully and caringly students are behaved and how truthfully, adequately, and timely they are provided with information. This conceptualization also includes justice principles that are associated with each dimension. Overall fairness refers to the global evaluation of fairness: how a student might evaluate a situation or action as 'fair.' Importantly, we assert that this framework must be considered and applied with the understanding that classrooms are heterogeneous contexts, where the evaluation of fairness in these contexts is situationally-dependent: what might be perceived as 'fair' using this framework in one context might not be perceived as fair in another. 
INSERT TABLE 4 HERE

\section{Classroom Distributive Justice}

Three justice principles are included for classroom distributive justice in our conceptualization: equity, equality, and need. Building on equity theory of Adams (1965), Sussman (1975) contends that students conceptualize equity through first comparing their contribution (e.g., effort, projects) with their outcome (e.g., grade) and then comparing their contribution and outcome with the contribution and outcome of a similar student; if the contribution-to-outcome ratio of the student is commensurate with the contribution-to-outcome ratio of a similar student, perception of justice might be arrived at while in the reverse case, where the distribution is disproportional, perception of injustice might be reached. Equality principle suggests that students might perceive justice when they are treated equally in terms of outcome distributions while the principle of need suggests that the outcome distribution is just when it is carried out based on students' needs.

These three principles are included in this dimension because theorists of organizational justice have long believed that equity, equality and need principles are the main justice principles for individuals' perception of distributive justice (Adams, 1965; Deutch, 1975). Similarly, the literature of classroom fairness has demonstrated that students apply the justice principles of equity, equality and need to arrive at the perception of justice in domains such as grading, instructor affect, and punishment (Berti, Molinari, \& Speltini, 2010; Horan, Chory, \& Goodboy, 2010; Thorkildsen, 1994).

\section{Classroom Procedural Justice}

Eight principles of consistency, accuracy, bias suppression, correctability, ethicality, voice, transparency, and reasonableness are identified for classroom procedural justice. Consistency refers to whether a teacher's application of classroom procedures is just. 
Consistency has been identified as a justice principle in organizational justice (Leventhal, 1980) and as a CA fairness theme (Authors) in areas such as grading (Camilli, 2006), attendance policy, punishment (Robbins \& Jeffords, 2009), promise-keeping (Horan et al., 2010), and course content (Rodabaugh, 1994).

Accuracy refers to whether classroom procedures are carried out correctly. In addition to being a procedural justice principle in organizational justice (Leventhal, 1980), accuracy has been documented to be associated with the students' perception of justice in domains such as grading (Alm \& Colnerud, 2015; Fellenz, 2006) and attendance policy (Rodabaugh, 1994).

Bias suppression refers to the enactment of classroom procedures neutrally, without involving a personal bias. Bias suppression is not only identified as a principle in organizational justice (Leventhal, 1980), but also has been reported to contribute to students' perception of classroom procedural justice (Kazemi, 2016). Although grading has been identified as a domain for the principle of bias suppression (Kazemi, 2016), additional domains such as attendance policy and punishment are speculated to implicate this justice principle.

Correctability considers a teacher's ability to correct wrong decisions. Drawing on the justice principle of correctability in Leventhal's (1980) framework, it is speculated that students might refer to this justice principle in domains such as grading, attendance policy, punishment, and tests.

Ethicality can be defined as whether classroom procedures uphold moral standards. In this respect, two domains of peer cheating and unethical authorship are identified as associated with this justice principle. Peer cheating, identified as a novel theme in the qualitative study on Iranian students' perception of CA fairness (Authors), refers to students' perception of injustice from teachers who are indifferent about the cheating of some other students in the classroom 
exam. Unethical authorship, where the contribution of a student is not recognized in a publication by the professor, was not only identified as unfair in the above manuscript, but has also been reported to contribute to the perception of injustice by several studies (e.g., Izadinia, 2014).

Voice refers to whether students have the opportunity to articulate their opinions. Previous research has demonstrated the negative impact of lack of voice in the grading domain and assessment procedures (Murillo \& Hidalgo, 2017; Tata, 2005). It is also speculated that students might perceive (in)justice if they are provided with or deprived of voice in domains such as classroom attendance policy, syllabus, punishment, workload, scheduling of make-up classes, and missed work.

Transparency refers to the clear enactment of classroom procedures. Previous research in CA has emphasized the significance of transparency for fairness (Tierney, 2013). Although transparency is usually invoked in the domain of grading (Pepper \& Pathak, 2008), it can also influence perception of justice in domains such as syllabus and attendance policy.

Finally, reasonableness takes into account the meaningful enactment of classroom procedures such as assignments (Houston \& Bettencourt, 1999; Whalen \& Koernig, 2009) and tests (Rodabaugh, 1994).

\section{Classroom Interactional Justice}

Four principles of respect, caring, adequate, truthful, and justified information, and timeliness are identified for classroom interactional justice. The principle of respect, which refers to the enactment of procedures with decorum and politeness, has already been identified as a key factor for individuals' justice perception in the literature of organizational justice theory (Bies \& Moag, 1986). Likewise, studies in CA (Cowie, 2015; Green et al., 2007; Tierney, 2016) and 
classroom fairness (Buttner, 2004; Horan \& Myers, 2009; Houston \& Bettencourt, 1999) have noted the influential impact of respect in students' perception of justice in terms of feedback and interpersonal relationships.

Caring, supportive, considerate and affective interpersonal relationship of a teacher with students, indicates that teachers' concern, kindness, and interest in students' learning is related to students' perception of interactional justice (Buttner, 2004; Colnerud, 2006) while lack of kindness (Chory, 2007; Horan et al., 2010), failure to remember students' names (Buttner, 2004), and failure to answer questions effectively, and interact enjoyably with students (Young, Horan, \& Frisby, 2013) are associated with students’ perception of interactional injustice.

Adequate, truthful, and justified information relates to teachers' reactive and proactive ability to communicate and explain information adequately and correctly, leading to individuals' perception of interactional justice (Bies \& Moag, 1986). Similarly, the scholarship in classroom fairness (Buttner, 2004; Colquitt, 2001; Oppenheimer, 1989) has identified adequacy, truthfulness, and justification as themes contributing to students' perception of interactional justice. We believe that students' perception of justice regarding this principle can be invoked in two domains of proactive and reactive information drawing on the distinction made between these two forms by Kazemi (2016). He argues that proactive information (e.g., teacher's adequate justification of the classroom attendance policy prior to students' requests) can contribute to students' perception of interactional justice independently from other dimensions of justice. However, the reactive information (e.g., teacher's justification of classroom attendance policy subsequent to students' perception of injustice) can be used to alleviate the perception of injustice aroused by other dimensions. 
A similar distinction can also be made between reactive and proactive information in the principle of timeliness, which refers to whether teacher has communicated the information to students on time, both prior to their request and after their request. This principle was deemed to contribute to the individual's perception of interactional justice in organizational justice theory (Cropanzano et al., 2015). Generalizing this principle to CA, students might consider timeliness in provision of feedback and classroom procedures as contributing to their perception of justice.

In summary, the conceptualization of CA fairness in this study argues that students evaluate fairness subjectively through three dimensions: classroom distributive justice, classroom procedural justice, and classroom interactional justice. Fairness evaluations subsequently lead to cognitive, emotional, and behavioral reactions by students. Students understand distributive justice through distribution of outcomes based on the principles of equity, equality, and need. Students understand procedural justice if classroom procedures are consistent, accurate, biasfree, correctable, ethical, representative of student voice, transparent, and reasonable. Students understand interactional justice based on respectful and caring treatment and receipt of adequate, truthful, justified, and timely information. Collectively, students' perception of fairness based on these the justice principles brings about positive emotional, cognitive, and behavioral for them. In this way, this conceptualization provides a multi-faceted understanding for fairness embedded within the interplay of socio-cultural ambience of CA contexts.

\section{Conclusion}

In an effort to address critiques over the inadequacy of CA fairness definitions and theories (Tierney, 2013, 2014), this paper has analyzed current CA fairness literature from the lens of organizational justice theory to provide a more comprehensive conceptualization for CA fairness that recognizes the heterogenous and situational nature of CA contexts. While this 
conceptualization is only an initial step in deepening our understandings of CA fairness, we argue that it begins to account for the procedural, interactional, and distributive processes that condition perceptions of CA fairness. We further recognize that this conceptualization does not provide an exhaustive list of justice principles and their associated domains in the context of CA; however, it does provide a promising platform for CA researchers to probe into students' perception of fairness, which can subsequently help to refine fairness theories and definitions. Accordingly, we encourage additional research into how fairness is conceptualized, practiced, and perceived in K-12 CA contexts. Specifically, we suggest the following lines of research. First, qualitative studies should be conducted across contexts to identify possible additional justice principles and their associated domains as related to teaching and learning. This research can help define CA fairness from students' perspectives more thoroughly.

Second, our conceptualization can directly be used to construct CA fairness instrument to assess students' perception of justice and fairness. The measurement of students' perception of justice and fairness has several merits. First, it will demonstrate to what extent this theoretical conceptualization can adequately account for students' perception of CA fairness. Second, the organizational justice model (Figure 2), can be empirically examined in the classroom context. Third, justice-moderator variables such as belief in a just world (Peter \& Dalbert, 2010), personality types, and learning styles can be measured along with the justice principles to identify their exclusive contributions to students' perception of fairness, which can help provide further empirical evidence on whether fairness and justice are empirically distinct.

Finally, drawing on the second portion of our definition of CA fairness, to consider the affective, cognitive, and behavioral consequences of fairness on students' learning, we suggest future research into the impact of students' perception of fairness on their cognitive learning, 
affective learning, motivation, and likelihood of cheating. Collectively, these avenues for research will help expand our conceptualization of fairness in CA by providing empirical evidence on various dimensions of the definition, and position the field to move forward with more in-depth understanding of this multidimensional conceptualization of fairness. 


\section{References}

Adams, J. S. (1965). Inequity in social exchange. In L. Berkowitz (Ed.), Advances in experimental social psychology (Vol. 2, pp. 267-299 ). New York: Academic Press.

Alm, F., \& Colnerud, G. (2015). Teachers' experiences of unfair grading. Educational Assessment, 20, 132-150. doi:10.1080/10627197.2015.1028620

Ambrose, M. L., \& Schminke, M. (2009). The role of overall justice judgments in organizational justice research: A test of mediation. Journal of Applied Psychology, 94, 491-500. doi:10.1037/a0013203

American Educational Research Association, American Psychological Association, \& National Council on Measurement in Education, (2014). Standards for educational and psychological testing. Washington, DC: American Educational Research Association.

Andrade, H. L. (2013). Classroom assessment in the context of learning theory and research. In J. H. McMillan (Ed.), Sage handbook of research on classroom assessment (pp. 17-34). Los Angeles, CA: Sage.

Berti, C., Molinari, L., \& Speltini, G. (2010). Classroom justice and psychological engagement: Students' and teachers' representations. Social Psychology of Education, 13, 541-556. doi:10.1007/s11218-010-9128-9

Bies, R. J., \& Moag, J. S. (1986). Interactional justice: Communication criteria of fairness. In R. J. Lewicki, B. H. Sheppard \& M. H. Bazerman (Eds.), Research on negotiation in organizations (Vol. 1, pp. 43-55). Greenwich, CT: JAI Press.

Bobocel, D. R., \& Gosse, L. (2015). Procedural justice: A historical review and critical analysis. In R. Cropanzano \& M. Ambrose (Eds.), The oxford handbook of justice in the workplace (pp. 51-88). Oxford, UK: The Oxford University Press. 
Brookhart, S. M. (2004). Classroom assessment: Tensions and intersections in theory and practice. Teachers College Record, 106, 429-458. doi:10.1111/j.14679620.2004.00346.x

Buttner, E. H. (2004). How do we "dis" students?: A model of (dis)respectful business instructor behavior. Journal of Management Education, 28, 319-334. doi:10.1177/1052562903252656

Byrne, Z. S., \& Cropanzano, R. (2001). The history of organizational justice: The founders speak. In R. Cropanzano (Ed.), Justice in the workplace: From theory to practice (Vol. 2, pp. 3-26). Mahwah, NJ: Erlbaum.

Camilli, G. (2006). Test fairness. In R. Brennan (Ed.), Educational measurement (4 ed., pp. 221256). Westport, CT: American Council on Education and Praeger.

Chory-Assad, R. (2002). Classroom justice: Perceptions of fairness as a predictor of student motivation, learning, and aggression. Communication Quarterly, 50, 58-77. doi:10.1080/01463370209385646

Chory-Assad, R., \& Paulsel, M. (2004b). Antisocial classroom communication: Instructor influence and interactional justice as predictors of student aggression. Communication Quarterly, 52, 98-114. doi:10.1080/01463370409370184

Chory, R. (2007). Enhancing student perceptions of fairness: The relationship between instructor credibility and classroom justice. Communication Education, 56, 89-105. doi:10.1080/03634520600994300

Colnerud, G. (2006). Teacher ethics as a research problem: Syntheses achieved and new issues. Teachers and Teaching: Theory and Practice, 12, 365-385. doi:10.1080/13450600500467704 
Colquitt, J. A. (2001). On the dimensionality of organizational justice: A construct validation of a measure. Journal of Applied Psychology, 86, 386-400. doi:10.1037/0021-9010.86.3.386

Colquitt, J. A., Conlon, D. E., Wesson, M. J., Porter, C. O., \& Ng, K. Y. (2001). Justice at the millennium: A meta-analytic review of 25 years of organizational justice research. Journal of Applied Psychology, 86, 425-445. doi:10.1037/0021-9010.86.3.425

Colquitt, J. A., \& Rodell, J. B. (2015). Measuring Justice and Fairness. In R. Cropanzano \& M. Ambrose (Eds.), The oxford handbook of justice in the workplace (pp. 187-202). Oxford, UK: The Oxford University Press.

Colquitt, J. A., \& Shaw, J. (2005). How should organizational justice be measured. In J. Greenberg \& J. A. Colquitt (Eds.), Handbook of organizational justice (Vol. 1, pp. 113152). Mahwah, NJ: Erlbaum.

Cowie, B. (2015). Equity, ethics and engagement: Principles for quality formative assessment in primary science classrooms. In C. Milne, K. Tobin \& D. DeGennaro (Eds.), Sociocultural studies and implications for science education (pp. 117-133). Netherlands: Springer.

Cowie, B., \& Bell, B. (1999). A model of formative assessment in science education. Assessment in Education: Principles, Policy \& Practice, 6, 101-116. doi:10.1080/09695949993026

Cropanzano, R., Fortin, M., \& Kirk, J. F. (2015). How do we know when we are treated fairly? Justice rules and fairness judgments. In M. R. Buckley, A. R. Wheeler \& J. R. B. Halbesleben (Eds.), Research in personnel and human resources management (pp. 279350): Emerald Group Publishing Limited.

Cropanzano, R., \& Greenberg, J. (1997). Progress in organizational justice: Tunneling through the maze. In I. T. Robertson \& C. L. Cooper (Eds.), International review of industrial and organizational psychology (pp. 317-372). London: Wiley. 
Crosthwaite, P., Bailey, D., \& Meeker, A. (2015). Assessing in-class participation for EFL: Considerations of effectiveness and fairness for different learning styles. Language Testing in Asia 5, 1-19. doi:10.1186/s40468-015-0017-1

DeLuca, C., LaPointe-McEwan, D., \& Luhanga, U. (2016). Teacher assessment literacy: A review of international standards and measures. Educational Assessment, Evaluation and Accountability, 1-22. doi:10.1007/s11092-015-9233-6

Deutsch, M. (1975). Equity, equality, and need: What determines which value will be used as the basis of distributive justice? Journal of Social Issues, 31, 137-149. doi:10.1111/j.15404560.1975.tb01000.x

Duplaga, E. A., \& Astani, M. (2010). An exploratory study of student perceptions of which classroom policies are fairest. Decision Sciences Journal of Innovative Education, 8, 933. doi:10.1111/j.1540-4609.2009.00241.x

Fellenz, M. (2006). Toward fairness in assessing student groupwork: A protocol for peer evaluation of individual contributions. Journal of Management Education, 30, 570-591. doi:10.1177/1052562906286713

Folger, R., \& Cropanzano, R. (1998). Organizational justice and human resource management. Newbury Park, CA: Sage Publications.

Frankena, W. K. (1973). Ethics. Foundations of philosophy series. Prentice-Hall, Englewood Cliffs, New Jersey.

Gipps, C., \& Stobart, G. (2009). Fairness in assessment. In C. Wyatt-Smith., \& J. Joy Cumming (Ed.), Educational assessment in the 21st century (pp. 105-118). London: Springer.

Goldman, B., \& Cropanzano, R. (2015). "Justice" and "fairness" are not the same thing. Journal of Organizational Behavior, 36, 313-318. doi:10.1002/job.1956/full 
Grace, C. C. (2017). Exploring the potential for and promise of incorporating distributive and procedural justices into post-secondary assessment of student learning. Teaching in Higher Education, 22, 304-317. doi:10.1080/13562517.2016.1248388

Green, S., Johnson, R., Kim, D., \& Pope, N. (2007). Ethics in classroom assessment practices: Issues and attitudes. Teaching and Teacher Education, 23, 999-1011. doi:10.1016/j.tate.2006.04.042

Greenberg, J. (1987). A taxonomy of organizational justice theories. Academy of Management review, 12, 9-22. doi:10.5465/AMR.1987.4306437

Greenberg, J. (1993). The social side of fairness: Interpersonal and informational classes of organizational justice. In R. Cropanzano (Ed.), Justice in the workplace: Approaching fairness in human resource management (pp. 79-103). Mahwah, NJ: Erlbaum.

Greenberg, J. (2011). Organizational justice: The dynamics of fairness in the workplace. In S. Zedeck (Ed.), Handbook of industrial and organizational psychology (Vol. 3, pp. 271327). Washington, DC: APA Press.

Holmgren, J., \& Bolkan, S. (2014). Instructor responses to rhetorical dissent: Student perceptions of justice and classroom outcomes. Communication Education, 63, 17-40. doi:10.1080/03634523.2013.833644

Horan, S. M., Chory, R., \& Goodboy, A. (2010). Understanding students' classroom justice experiences and responses. Communication Education, 59, 453-474.

doi:10.1080/03634523.2010.487282

Horan, S. M., \& Myers, S. (2009). An exploration of college instructors' use of classroom justice, power, and behavior alteration techniques. Communication Education, 58, 483-496. doi:10.1080/03634520903055981 
Houston, M., \& Bettencourt, L. (1999). But that's not fair! An exploratory study of student perceptions of instructor fairness. Journal of Marketing Education, 21, 84-96. doi:10.1177/0273475399212002

Izadinia, M. (2014). Authorship: The hidden voices of postgraduate TEFL students in Iran. Journal of Academic Ethics, 12, 317-331. doi:10.1007/s10805-014-9215-1

JCSEE. (2003). The student evaluation standards. Arlen Gullickson, Chair. Thousand Oaks, CA: Corwin.

Karriker, J. H., Williams, M. L., \& Williams, L. J. (2017). Direct and Indirect Assessments of Organizational Justice: Homogeneity or Harmony? Journal of Organizational Psychology, 17, 52-68.

Kazemi, A. (2016). Examining the interplay of justice perceptions, motivation, and school achievement among secondary school students. Social Justice Research, 29, 103-118. doi:10.1007/s11211-016-0261-2

Kazemi, A., \& Törnblom, K. (2008). Social psychology of justice: Origins, central issues, recent developments, and future directions. Nordic Psychology, 60, 209-234. doi:10.1027/19012276.60.3.209

Klenowski, V. (2009). Australian Indigenous students: Addressing equity issues in assessment. Teaching Education, 20, 77-93. doi:10.1080/10476210802681741

Klenowski, V. (2014). Towards fairer assessment. The Australian Educational Researcher, 41, 445-470. doi:10.1007/s13384-013-0132-x

Lantolf, J., \& Poehner, M. (2013). The unfairness of equal treatment: Objectivity in L2 testing and dynamic assessment. Educational Research and Evaluation, 19, 141-157. doi:10.1080/13803611.2013.767616 
Leventhal, G. (1980). What should be done with equity theory? New approaches to the study of justice in social relationships. In K. Gergen, M. Greenberg \& R. Willis (Eds.), Social exchange: Advances in theory and research (Vol. 9, pp. 27-55). New York: Plenum Press.

Liu, J., Johnson, R., \& Fan, X. (2016). A comparative study of Chinese and United States preservice teachers' perceptions about ethical issues in classroom assessment. Studies in Educational Evaluation, 48, 57-66. doi:10.1016/j.stueduc.2016.01.002

Lizzio, A., \& Wilson, K. (2008). Feedback on assessment: Students' perceptions of quality and effectiveness. Assessment \& Evaluation in Higher Education, 33, 263-275. doi:10.1080/02602930701292548

McMillan, J. H. (Ed.). (2013). Sage handbook of research on classroom assessment. Thousand Oaks, CA: Sage Publications.

McMillan, J. H. (2013). Why we need research on classroom assessment. In J. H. McMillan (Ed.), Sage Handbook of Research on Classroom Assessment (pp. 3-16). Thousand Oaks, CA: Sage Publications, Inc.

Mikula, G. (2005). Some observations and critical thoughts about the present state of justice theory and research. In S. W. Gilliland, D. D. Steiner, D. P. Skarlicki \& K. V. d. Bos (Eds.), What motivates fairness in organizations (pp. 197-210). Greenwich, CT: Information Age Publishing.

Murillo, F. J., \& Hidalgo, N. (2017). Students' conceptions about a fair assessment of their learning. Studies in Educational Evaluation, 53, 10-16.

doi:10.1016/j.stueduc.2017.01.001 
Nicklin, J. M., Greenbaum, R., McNall, L. A., Folger, R., \& Williams, K. J. (2011). The importance of contextual variables when judging fairness: An examination of counterfactual thoughts and fairness theory. Organizational behavior and human decision processes, 114, 127-141. doi:10.1016/j.obhdp.2010.10.007

Nisbet, I. (2017). Fairness takes centre stage. Assessment in Education: Principles, Policy \& Practice, 1-7. doi:10.1080/0969594X.2017.1358151

Oppenheimer, R. (1989). Fairness in the classroom: An empirical extension of the notion of organizational justice. Developments in Business Simulation and Experiential Learning, 16. Retrieved from https://journals.tdl.org/absel/index.php/absel/article/view/1867

Ortiz, S. O. (2002). Best practices in nondiscriminatory assessment. In A. Thomas \& J. Grimes (Eds.), Best Practices in School Psychology (pp. 1321-1336). Bethesda, MD: National Association of School Psychologists.

Pepper, M., \& Pathak, S. (2008). Classroom contribution: What do students perceive as fair assessment? Journal of Education for Business, 360-368 doi:10.3200/JOEB.83.6.360-368

Peter, F., \& Dalbert, C. (2010). Do my teachers treat me justly? Implications of students' justice experience for class climate experience. Contemporary Educational Psychology, 35, 297 305. doi:10.1016/j.cedpsych.2010.06.001

Poehner, M. (2011). Dynamic assessment: Fairness through the prism of mediation. Assessment in Education: Principles, Policy \& Practice, 18, 99-112. doi:10.1080/0969594X.2011.567090

Pope, N., Green, S. K., Johnson, R. L., \& Mitchell, M. (2009). Examining teacher ethical dilemmas in classroom assessment. Teaching and Teacher Education, 25, 778-782. doi:10.1016/j.tate.2008.11.013 
Rasooli, A. (2016). Advanced Iranian English Language Students’ Perception of Classroom Fairness: Numbers and Words Talk. Unpublished master's thesis, University of Tehran, Tehran, Iran.

Rasooli, A., Zandi, H., \& DeLuca, C. (2018). Re-conceptualizing classroom assessment fairness: A systematic meta-ethnography of assessment literature and beyond. Studies in Educational Evaluation, 56, 164-181. doi:10.1016/j.stueduc.2017.12.008

Robbins, T. L., \& Jeffords, B. C. (2009). Practising what we preach: Justice and ethical instruction in management education. Ethics and Education, 4, 93-102. doi:10.1080/17449640902861562

Rodabaugh, R. C. (1994). College students' perceptions of unfairness in the classroom. Retrieved from http://digitalcommons.unl.edu/podimproveacad/319.

Rodell, J. B., Colquitt, J. A., \& Baer, M. D. (2017). Is adhering to justice rules enough? The role of charismatic qualities in perceptions of supervisors' overall fairness. Organizational behavior and human decision processes, 140, 14-28. doi:10.1016/j.obhdp.2017.03.001

Rogers, W. T. (1996a). Principles for fair student assessment practices for education in Canada. Assessment in Education: Principles, Policy \& Practice, 3, 397-400. doi:10.1080/0969594960030308

Rogers, W. T. (1996b). Principles for fair student assessment practices for education in Canada. Assessment in Education: Principles, Policy \& Practice, 3, 413-432.

Sabbagh, C. (2009). Ethics and teaching. In L. J. Saha \& A. G. Dworkin (Eds.), International handbook of research on teachers and teaching (pp. 683-693). New York: Springer. 
Scott, S., Webber, C. F., Lupart, J. L., Aitken, N., \& Scott, D. E. (2014). Fair and equitable assessment practices for all students. Assessment in Education: Principles, Policy \& Practice, 21, 52-70. doi:10.1080/0969594X.2013.776943

Shepard, L. (2001). The role of classroom assessment in teaching and learning. In V. Richardson (Ed.), Handbook of research on teaching (Vol. 4th edition, pp. 1066-1101). Washington, DC: AERA.

Siegel, M. (2014). Developing preservice teachers' expertise in equitable assessment for English learners. Journal of Science Teacher Education, 25, 289-308. doi:10.1007/s10972-0139365-9

Suskie, L. (2000). Fair assessment practices: Giving students equitable opportunities to demonstrate learning. American Association for Higher Education. Retrieved from http://www.ubc.ca/okanagan/ctl/_shared/assets/FairAssessmentPractices12732.pdf

Sussman, L. (1975). A theoretical analysis of equity and its relationship to student evaluation. Southern Journal of Communication, 40, 321-334. doi:10.1080/10417947509372275

Tata, J. (2005). The influence of national culture on the perceived fairness of grading procedures: A comparison of the United States and China. The Journal of Psychology, 139, 401-412. doi:10.3200/JRLP.139.5.401-412

Thibaut, J. W., \& Walker, L. (1975). Procedural justice: A psychological analysis. Hillsdale, NJ: L. Erlbaum Associates.

Thorkildsen, T. A. (1994). Through students' eyes: A fair classroom. Update on Law-Related Education, 18, 56-62. 
Tierney, R. (2013). Fairness in classroom assessment. In J. H. McMillan (Ed.), Sage handbook of research on classroom assessment (pp. 125-144). Thousand Oaks, CA: SAGE Publications.

Tierney, R. (2014). Fairness as a multifaceted quality in classroom assessment. Studies in Educational Evaluation, 43, 55-69. doi:10.1016/j.stueduc.2013.12.003

Tierney, R. (2016). Fairness in Educational Assessment. In M. A. Peters (Ed.), Encyclopedia of Educational Philosophy and Theory (pp. 1-6). Singapore: Springer Singapore.

Volante, L. (2006). Reducing bias in classroom assessment and evaluation. Orbit, 36, 34-36.

Whalen, D. J., \& Koernig, S. K. (2009). Maintaining fairness when a student goes afoul of classroom rules: A procedural justice model. Marketing Education Review, 19, 27-33. doi:10.1080/10528008.2009.11489071

Young, L., Horan, S., \& Frisby, B. (2013). Fair and square? An examination of classroom justice and relational teaching messages. Communication Education, 62, 333-351.

doi:10.1080/03634523.2013.800216 


\section{Conceptualizing Assessment Fairness}

\section{Appendix. Included studies of fairness in CA by Authors (2018)}

\begin{tabular}{lll}
\hline Study & $\begin{array}{l}\text { Time of } \\
\text { publication }\end{array}$ & $\begin{array}{l}\text { Type of } \\
\text { Study }\end{array}$ \\
\hline $\begin{array}{l}\text { Abedi, Hofstetter, \& } \\
\begin{array}{l}\text { Lord } \\
\text { Siegel, Wissehr, \& }\end{array}\end{array}$ & 2004 & Theoretical \\
Halverson & 2008 & Theoretical \\
\end{tabular}

Description of Study

This paper reviews the results of empirical studies in terms of the nature and types of accommodations that English Language Learners

Halverson

Ortiz

$2002 \quad$ Theoretical

Suskie

2002

Theoretical

Volante

2006

Theoretical

Scott, Webber, Lupart, 2014

Aitken \& Scott

Camilli

2013

Theoretical

Camilli

2006

Poehner

Lantolf \& Poehner

2011

Tierney

Gipps \& Stobart

2009

Klenowski

2009

Klenowski

Tillema, Leenknecht, \& 2011

Segers

Cowie

Gipps

1995

Fellenz

Tierney

2006

Siegel

2007

Flores, Simão, Barros

\& Pereira

Webb, Nemer, Chizhik,

1998

\& Sugrue

Falchikov \& Magin

1997

Barfield

2003
(ELL) receive. The study concludes that no single type of accommodations serves the needs of ELLs.

This study suggests a five-step equity framework to deal with accommodations for English Language Learners' written classroom assessments: (a) the modified test should be consistent with the objectives of the original test and language of instruction; (b) the modified test should consider the language ability and cultural background of students; ( $c$ and d) the modified test should be easy to understand but withhold the cognitive load of the original test; and (e) the teacher should give hints to help English Language Learners accomplish the task.

This study suggests ten criteria for nondiscriminatory assessment framework, which can be applied to all students. 1. Assess and evaluate the learning ecology; 2. Assess and evaluate language proficiency; 3. Assess and evaluate opportunity for learning; 4 . Assess and evaluate educationally relevant cultural and linguistic factors; 5 . Evaluate, revise, and re-test hypotheses; 6 . Determine the need for and language(s) of assessment; 7. Reduce bias in traditional testing practices; 8. Utilize authentic and alternative assessment procedures; 9. Evaluate and interpret all data within the context of the learning ecology; and 10. Link assessment to intervention (p. 8) This paper suggests several strategies to ensure fair assessment: (a) Have clearly stated learning outcomes; (b) Match your assessment to what you teach; (c) Use many different measures and many different kinds of measures; (d) Help students learn how to do the assessment task; (e) Engage and encourage your students; (f) Interpret assessment results appropriately; and (g) Evaluate the outcomes of your assessments (pp. 2-3)

This paper suggests several strategies to enhance fairness in assessment: (a) Examine how your classroom complements or conflicts with the school experiences and assessment techniques which are familiar to recent immigrants and indigenous people; (b) Develop test questions and other assessment items that reflect the multicultural and multiethnic composition of your school, district, region, province, country; (c) Utilize gender-neutral terms within tests, quizzes, and other forms of assessment; (d) Provide modifications to tests and other assessment measures for students with exceptionalities and those with limited proficiency in English; (e) Take steps to reduce the effects of test-wiseness on academic achievement - design carefully constructed test items, utilize multiple-formats, provide reviews prior to testing; (f) Involve students in the development of evaluation criteria-develop rubrics with the assistance of students; (g) Adopt a range of formative and summative assessment strategies that encompass different ways of demonstrating task mastery speaking, writing, performing; (h) Balance the weight given to different types of traditional and authentic performance-based assessment data when arriving at final course grades; and (i) Most importantly, reflect on preconceived notions that may affect the mark/grades you assign to particular groups of student. (p. 35)

Theoretical Building on the findings of interviews and questionnaires, this study suggests five principles for fair assessment practice. First, educators must strive to understand and address the personal impact of assessment practices on individual students and their families. Second, assessment must be differentiated to accommodate the ability, social, cultural and linguistic background of every student. Third, all members of school communities must challenge the complacency associated with accepting indefensible and illogical assessment practices. Fourth, the frequency, intensity and intrusiveness of assessments must not be overwhelming for students and their families. Finally, assessment must not be confused as a mechanism to counter inappropriate student behaviour or reward desired behaviour. (p. 66)

This study reviews fairness in three areas: first, fairness issues such as DIF and accommodations in large-scale assessment contexts were examined; second, fairness in terms of employment-testing were reviewed; and finally, fairness in classroom assessment was analyzed, where the author reported that "classroom assessment is by far the most prevalent type of testing, yet most formal methods

$\begin{array}{ll}\text { Theoretical } & \text { of test fairness are restricted to large-scale assessment." (p. 116). } \\ \text { This book chapter reviews the statistical methods and common strategies that can be employed to enact fair testing practice. Several }\end{array}$ strategies were suggested in this study for classroom fairness: clarity and consistency of assessment criteria, multiple opportunities for assessment, use of multiple assessment instruments, cultural and religious considerations in assessment.

Theoretical This paper attempts to re-conceptualize assessment fairness based on Vygostkiyan concept of zone of proximal development.

Theoretical This paper is another attempt to reframe theory of assessment fairness through Vygostkiyan concept of zone of proximal development.

Theoretical This book chapter reviews the standards and empirical and conceptual studies in classroom assessment to provide a renewed conception of classroom assessment fairness. Transparency, constructive classroom environment, teacher reflection, and the relationship between equity and equality were discussed as relevant to classroom assessment fairness theory.

Theoretical This book chapter discusses that assessment fairness should be conceptualized beyond test fairness to incorporate opportunity to learn prior to assessment.

Theoretical This paper, building on the works of Gipps and Stobart (2009), argues for the need to re-conceptualize assessment fairness beyond fairness of tests to consist of issues prior to assessment (i.e. access to resources and material) in relation to indigenous students.

Theoretical This paper, building on the works of Gipps and Stobart (2009), Courtney and Cazden (2012), and Nansy Fraser's theory of social justice, considers the fairness of a major summative evaluation in relation to indigenous students in Australia. The author conceptualizes fairness of assessment practices in relation to access to resources for indigenous students and representation of indigenous students' cultural values summative evaluation.

Theoretical This study systematically reviewed the literature of peer assessment for learning to identify the criteria according to which peer assessments are constructed. Fairness was found as one of the key considerations in building peer assessment criteria.

Theoretical This book chapter discusses three alternative criteria for validity and reliability in classroom assessment, which includes equity, student engagement, and ethic of care

Theoretical This study attempts to define equity for assessment as inclusive of equality of access and equality on testing process, while excluding equality of outcome.

Theoretical This paper suggests a several procedural criteria for enchantment of fairness in peer assessment.

Theoretical This book chapter reviews the evolution of fairness concept in assessment and identifies four themes that enhance fairness in classroom assessment: transparency, opportunity to learn and demonstrate learning, constructive environment, and evaluative reflection

Quantitative This study examined the effect of accommodations (e.g., simplifying the language, visualization, etc.) on the performance of English Language Learners and Native English Speakers on written classroom assessments. Both groups had a better performance in modified tests.

Quantitative This study examined students' perception of fairness in terms of learning-centered assessment vs. traditional assessment. The results indicated that students considered learner-centered assessment methods such as portfolio and project work as fairer than traditional methods of assessment such written tests and exams.

Quantitative This study examined the effect of group composition on students' performance and found that group composition where high-ability students are teamed with low-ability students, can disadvantage the performance ceiling of high-ability students.

Quantitative This study explored if sex bias can affect the fairness, validity, and reliability of peer assessment negatively. The authors found no statistically significant difference derived by sex-bias.

Quantitative This study explored the effect of grade expectancy, hours spent in a job outside of the campus, and age on students' perception of fairness in terms of the grades they receive in a group. The author discovered that students without prior experience of group work 


\section{Conceptualizing Assessment Fairness}

Langan, Wheater,

Shaw , Haines, Cullen,

2005

Boyle, Penney,

Oldekop, Ashcroft,

Lockey \& Preziosi

Magin

2001

Panadero, Romero, \&

Strijbos

Crosthwaite, Bailey \&

Meeker

Pope, Green, Johnson, 2009

\& Mitchell

Green, Johnson, Kim, 2007

\& Pope

Gweon, Jun, Finger, \& 2017

Penstein Rose

Mauldin

Quantitative

Duffield \& Spencer

Johnson, Green, Kim, \& Pope

Liu, Johnson \& Fan

Peterson, Childs, \&

Kennedy

Siegel, Menon, Sinha, Promyod, Wissehr, \& Halverson

Sambell, McDowell \&

Brown

Tierney

Schissel

Siegel

Qualitative

Yung \& Yung

2001

Qualitative

Morgan, \& Watson

Qualitative

Tierney

2014

Qualitative

Aitken

2012

Qualitative

Alm \& Colnerud

2015

Qualitative

Murillo \& Hidalgo

2017 perceived equal grades as fair while experienced students considered equity. The author also reported that students with full-time job outside the campus regarded inequality of grades as fair. Moreover, older students perceived group grades more unfair than younger students.

This study investigated the influence of gender, students' university affiliation, and timing of presentations on students' perception of fairness of peer grades. The authors found that peers from the same university and gender (esp. males) rated higher than students from other universities or opposite sex. Timing of presentation also affected grades of students as lower marks were given to the middle of the day presentations.

Quantitative This study examined the effect of reciprocity in peers' assessment of a student in the group. No significant effect was observed for reciprocity.

This study investigated the effect of friendship on the fairness of peer assessment of concept maps. The authors demonstrated that students with high (i.e. intimate) friendship indicated a reciprocity effect; however, such pattern was not observed for low and mid friendships

This study investigated the impact of students' learning style (i.e., individual vs. project) on their perception of fairness of classroom participation grades. The results of study indicated that students with individual learning styles were disadvantaged in their classroom participation grades due to their inclination to work alone.

This study explored ethical dilemmas teachers have experienced during their classroom assessment practice. Findings of this study revealed that teachers' ethical dilemmas of classroom assessment falls within two ethical principles of Do No Harm and Avoid Score Pollution.

This study investigated teachers' ethical dilemmas of classroom assessment. They reported that teachers showed high agreement on the items addressing ethics of communication about grading, confidentiality, and multiple assessment opportunities but showed low agreement on items focusing on standardized test administration, grading practices, and addressing biases.

This study explored if instructors' assessments are affected by judgmental errors of halo effect and fundamental attribution theory when evaluating students' group work across five-dimensional assessment rubric (i.e. goal-setting, progress, knowledge coconstruction, participation, and teamwork). They found that the instructors' assessments were affected by halo effect as they provided similar scores across the dimensions of the rubric. Further, instructors' were found to provide similar scores for students within a group, which was known as fundamental attribution theory.

This study analyzed whether male and female students differed significantly in their perception of fairness when they were provided with multiple testing choices (i.e. constructed response, selective response, or mixed testing). No significant differences were found between two gender groups but females were observed to feel fairer than males when provided with testing choices.

This study surveyed the students' perception of fairness of assessments used in Newcastle Medical School. They found that the majority of students considered the assessments fair.

This study investigated administrators' perception of ethical dilemmas in classroom assessment. The findings indicated that administrators appear to lack consensus on what constitutes an ethical practice in items related to standardized test preparation, grading practices, bias and standardized test administration.

This study compared the perception of American and Chinese pre-service teachers about the ethicality of several classroom assessment practices. This study demonstrated that not only the perspective of American and Chinese pre-service teachers diverge in most of ethical scenarios in assessment, but also their points of view deviate from ethical standards in classroom assessment.

This study explored whether or not male and female teachers' scoring and provision of written feedback differ across two narrative and persuasive writing samples produced by male and female students. The authors found that teachers did not demonstrate consistent gender-biased pattern when giving scores and feedback.

This study examined the effect of accommodations on the performance of English Language Learners and Native English Speakers on written classroom assessments. Both English Language Learners and Native Speakers were found to perform better when provided with modified written assessment tasks.

Qualitative This study explored students' perception of traditional assessment vs. alternative assessment through interviews. One of the themes that students repeatedly raised in the interviews was the fact that they conceived alternative assessments as fairer than traditional assessments because traditional assessments tap skills and knowledge that are considered unimportant to students.

This study explored the reasons that teachers might consider when altering students' grades. Three themes were discovered: (a) teachers' compassion; (b) b) teachers' inclination to provide students with additional opportunities; and c) teachers' mission to teach life lessons.

This study explored how teachers use accommodations in actual summative assessments. The author demonstrated that teachers used similar accommodations for both English Language Learners and special education students. Moreover, accommodations were also provided for general education students, too.

This study probed into pre-service teachers' reflection of equitable assessment for English Language Learners after a course of instruction. After instruction, teachers reported increase in their metacognitive knowledge of accommodations; Nonetheless, they did not reveal this concern in their real tasks of assessment design.

This study explored three teachers' beliefs, understanding, and actual practice of formative assessment in biology classrooms. One of the major concerns that emerged in the data was the issue of fairness. Three teachers had different beliefs on how to make the formative assessment fair. The first teacher regarded formative assessment believed in assessment of students on an equality basis; second teacher implemented fairness in view of differentiated instruction in the classroom; and the third teacher believed in the necessity of providing students with all round education.

This study examines fairness of assessment in mathematics. The findings suggest that teachers might provide incomparable graded assessments for works with similar quality. Moreover, teachers might consider sources such as students' behavior and their own expectations in giving grades.

This study aimed to re-conceptualize fairness in classroom assessment through teachers' views. Drawing on the thematic analyses of interviews, the author argued that classroom assessment fairness is associated with five aspects of transparency, opportunity to and demonstrate learning, constructive classroom environment, equity and equality, and critical reflection.

This book chapter advocated further exploration of assessment fairness through students' voices. Moreover, the researcher thematically analyzed students' anecdotes to identify their conceptions of fairness. The findings indicated that students' conception of fairness includes diverse phases of assessment such as planning, collecting, scoring, interpreting and reporting assessment information. This study explored teachers' perspectives of unfair grading. The authors identified several themes that contributed to teachers' unfair perception when they were students: failure to apply the grading systems suggested by standards, use of insufficient, unsuitable, and insignificant data for scoring, alteration of grades due to reasons other than achievement, and failure to effectively communicate the reasons behind grades.

This study explored students' perception of fairness of assessment. Students' conceptions were found to be associated with two principles of equity and equality. Themes of transparency, similar exam conditions, and objective criteria, for example, were found as related to equality principle; yet, on the other hand, themes of adapting assessment to students' needs, provision of multiple assessments, and grades be reflective of progress and effort rather than just achievement were found as related to equity, for example. 


\section{Conceptualizing Assessment Fairness}

\begin{tabular}{|c|c|c|c|}
\hline Lizzio \& Wilson & 2008 & Mixed & $\begin{array}{l}\text { This study explored the characteristics and components of an effective teacher written feedback through students' perception. Four } \\
\text { dimensions were reported to be associated with an effective feedback: developmental focus (i.e., the potentials of feedback to improve } \\
\text { learning), engagement (i.e., feedback reflecting the extent teacher has studied their work carefully), encouragement (i.e., positive } \\
\text { feedback), and fairness (i.e., provision of clear, reasonable and consistent information). }\end{array}$ \\
\hline Carless & 2006 & Mixed & $\begin{array}{l}\text { This study explored the alignment between students and teachers' perceptions of effective written feedback. Findings indicated a } \\
\text { misalignment between students and teachers' perceptions of feedback. Unlike teachers, students felt that teachers' feedback was less } \\
\text { detailed and effective. However, both groups agreed that the criteria based on which assignments are corrected and graded were not } \\
\text { completely clear. Moreover, although teachers believed that their grading based on their feedback was fair; however, students did not } \\
\text { concur. }\end{array}$ \\
\hline Sivan & 2000 & Mixed & $\begin{array}{l}\text { Adopting action research, the author probed into how peer assessment can be best done in a classroom. Fairness was mentioned as an } \\
\text { enduring concern for students, which can be enhanced through students' involvement in developing assessment criteria. }\end{array}$ \\
\hline
\end{tabular}




\section{Figures}

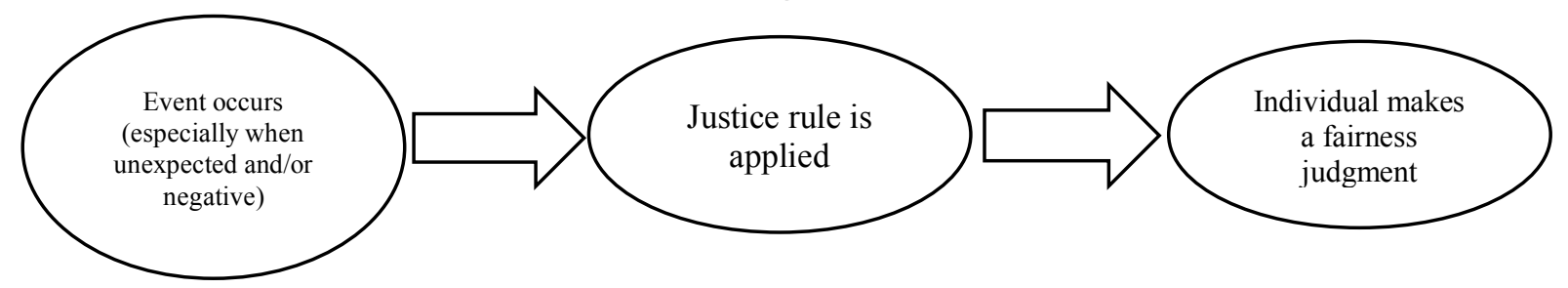

Note. Figure 1. Justice rules fairness judgments. Reprinted from "How we know when we are treated fairly? justice rules and fairness judgments" by R. Cropanzano, M. Fortin, J. F. Kirk, 2015, Research in Personnel and Human Resources Management, p. 282.

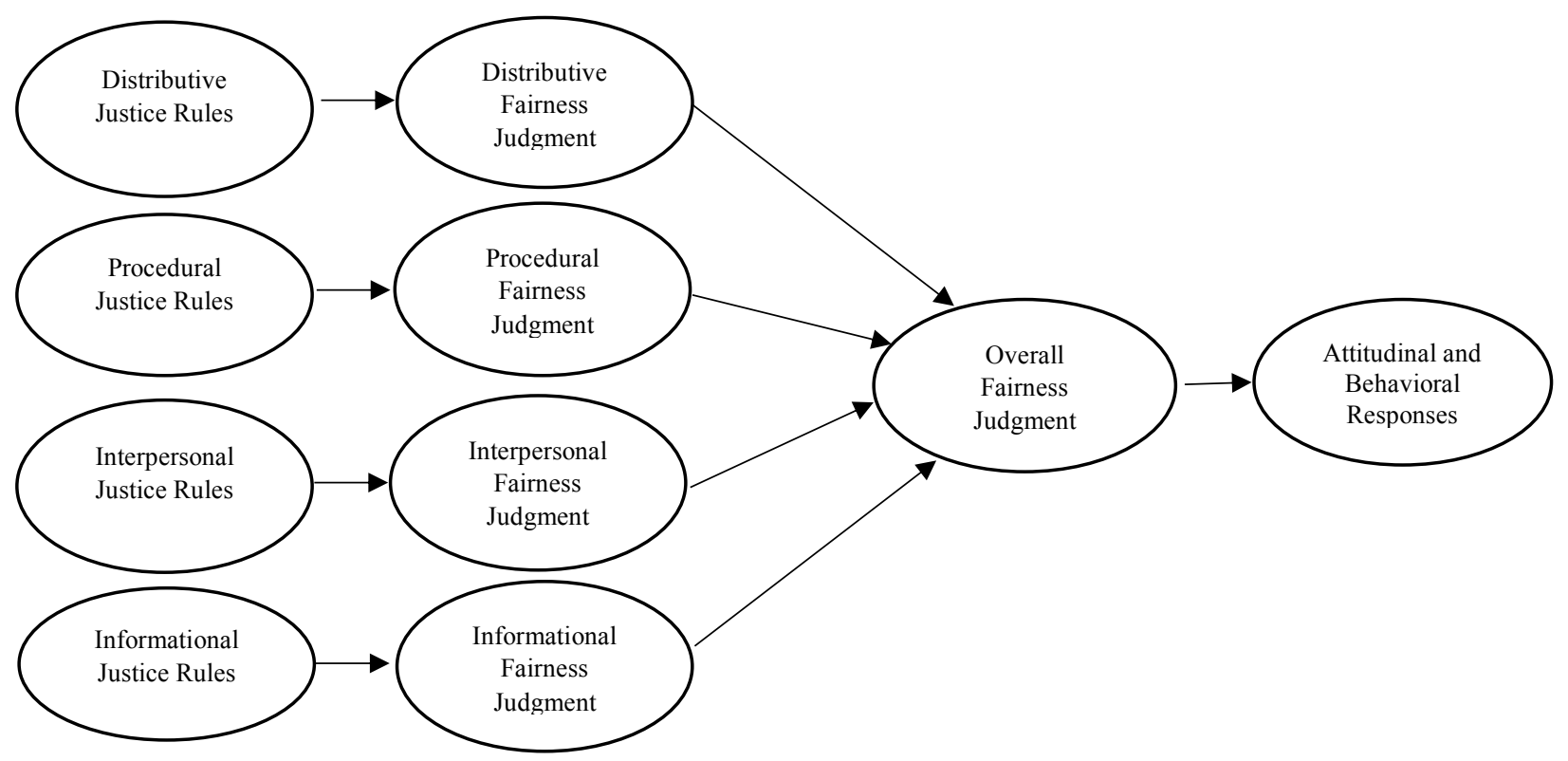

Note. Figure 2. Justice rules fairness judgments. Reprinted from "How we know when we are treated fairly? justice rules and fairness judgments" by R. Cropanzano, M. Fortin, J. F. Kirk, 2015, Research in Personnel and Human Resources Management, p. 324. 


\section{Tables}

Table 1 Definitions that are provided for fairness in classroom assessment

\begin{tabular}{|c|c|c|c|}
\hline Study & Year & $\begin{array}{l}\text { Keywords in the } \\
\text { definitions }\end{array}$ & Definitions of fairness \\
\hline Oritz & 2002 & Nondiscriminatory & $\begin{array}{l}\text { "nondiscriminatory assessment is not defined as a single procedure } \\
\text { or test, but as a wide range of approaches that collectively seek to } \\
\text { uncover as fairly as possible relevant information and data upon } \\
\text { which decisions regarding functioning and performance can be } \\
\text { equitably based. In other words, nondiscriminatory assessment is } \\
\text { not a search for an unbiased test but rather a process that ensures } \\
\text { every individual, not just those who are different in some way, is } \\
\text { evaluated in the least discriminatory manner possible" (p. 1) }\end{array}$ \\
\hline $\begin{array}{l}\text { Green, } \\
\text { Johnson, } \\
\text { Kim, \& Pope }\end{array}$ & 2007 & Ethics & $\begin{array}{l}\text { "The present authors define ethical behavior acting based on one's } \\
\text { judgment of an obligation" (p. 1000) }\end{array}$ \\
\hline $\begin{array}{l}\text { Gipps \& } \\
\text { Stobart }\end{array}$ & 2009 & $\begin{array}{l}\text { Fairness, equality, } \\
\text { equity, justice }\end{array}$ & $\begin{array}{l}\text { Fairness in assessment involves both what precedes an assessment } \\
\text { (for example, access and resources) and its consequences (for } \\
\text { example, interpretations of results and impact) as well as aspects of } \\
\text { the assessment design itself ( } \mathrm{p} .105 \text { ). } \\
\text { Equity represents the judgment about whether equality, be it in the } \\
\text { form of opportunity and/or of outcomes, achieves just ('fair') } \\
\text { results. Looking for equality requires essentially a quantitative } \\
\text { approach to differences between groups, while equity goes beyond } \\
\text { this and looks at the justice of the arrangements prior to the } \\
\text { assessment (p. 106) }\end{array}$ \\
\hline Klenowski & 2009 & $\begin{array}{l}\text { Equity, fairness, } \\
\text { justice }\end{array}$ & $\begin{array}{l}\text { "Equity relates to "fairness" or 'the application of the principles of } \\
\text { justice to correct or supplement the law' (Allen, 1990, p. 396). } \\
\text { Equity or fairness in assessment has recently been defined as 'a } \\
\text { qualitative concern for what is just' and a key assumption in the } \\
\text { discussion of equity in relation to assessment is that it is more of a } \\
\text { sociocultural issue than a technical one (Stobart, 2005, p. 275)" (p. } \\
\text { 82) }\end{array}$ \\
\hline Klenowski & 2014 & $\begin{array}{l}\text { Fairness, justice, } \\
\text { equity }\end{array}$ & $\begin{array}{l}\text { Fairness in assessment requires teachers and systems to consider } \\
\text { the social contexts of assessment and, as defined more broadly by } \\
\text { Gipps and Stobart (2009: 105), moves beyond the technical } \\
\text { definition of a concern with test construction to a more } \\
\text { encompassing view of "what precedes an assessment (for example, } \\
\text { access and resources)" or recognitive and redistributive justice. } \\
\text { Fairness in assessment from this view includes "its consequences } \\
\text { (for example, interpretations of results and impact) as well as } \\
\text { aspects of the assessment design itself" (Gipps and Stobart 2009: } \\
\text { 105). }\end{array}$ \\
\hline Poehner & 2011 & Fairness & $\begin{array}{l}\text { "Fairness in education, from this perspective, does not involve } \\
\text { treating all individuals as if they were the same, because doing so } \\
\text { ignores that they are not. Fairness requires doing everything } \\
\text { possible to maximally support individual learner development, } \\
\text { with the understanding that some individuals will need more time } \\
\text { and resources than others. Assessment represents a crucial first step } \\
\text { toward establishing educational fairness by mediating learners } \\
\text { toward success and taking stock of this process as it unfolds in } \\
\text { order to determine, with learners, where to go next." (p. 103). }\end{array}$ \\
\hline
\end{tabular}




\begin{tabular}{lcll}
\hline Siegel & 2014 & $\begin{array}{l}\text { Equitable } \\
\text { assessment }\end{array}$ & $\begin{array}{l}\text { "Assessments that are equitable provide equal opportunities for } \\
\text { students to demonstrate what they know using procedures most } \\
\text { appropriate to the individual learner based upon factors such as } \\
\text { their language ability and culture" (p. 290) }\end{array}$ \\
$\begin{array}{l}\text { Liu, Johnson } \\
\text { \& Fan }\end{array} 2016$ & $\begin{array}{l}\text { Ethics in the field of educational assessment, ethics has been described } \\
\text { assessment }\end{array}$ & $\begin{array}{l}\text { as rules of behavior or practices that a profession imposes on } \\
\text { itself" (p. 57). }\end{array}$ \\
\hline
\end{tabular}

Table 2 Theories that have been used for fairness in classroom assessment

\begin{tabular}{lll}
\hline Study & Year & Theoretical Framework \\
\hline Green, Johnson, Kim, \& Pope & 2007 & Do no harm and avoid score pollution \\
Lizzio \& Wilson & 2008 & Organizational justice theory (procedural justice dimension) \\
Pope, Green, Johnson, \& Mitchell & 2009 & Do no harm and avoid score pollution \\
Poehner & 2011 & Equitable access to mediation \\
Lantolf \& Poehner & 2013 & Equitable access to mediation \\
Tierney & 2014 & Phronesis \\
Alm \& Colnerud & 2015 & Principles of equality, need and equity \\
Cowie & 2015 & Ethic of care, equity, and active student engagement \\
Liu, Johnson \& Fan & 2016 & Do no harm and avoid score pollution \\
Murillo \& Hidalgo & 2017 & Egalitarian and equitable fair assessment \\
\hline
\end{tabular}

Table 3 Justice dimensions and their principles

\begin{tabular}{|c|c|c|}
\hline Dimensions of Justice & Justice principles & Descriptions \\
\hline \multirow{3}{*}{$\begin{array}{l}\text { Distributive (Adams, 1965; } \\
\text { Deutsch, 1975) }\end{array}$} & Equity & Outcomes are distributed based on contributions \\
\hline & Equality & Outcomes are distributed equally \\
\hline & Need & Outcomes are distributed based on needs \\
\hline \multirow[t]{6}{*}{$\begin{array}{l}\text { Procedural (Thibaut \& Walker, } \\
\text { 1975; Leventahal, 1980) }\end{array}$} & Consistency & $\begin{array}{l}\text { Procedures are implemented consistently across } \\
\text { people and time }\end{array}$ \\
\hline & Voice (or representativeness) & $\begin{array}{l}\text { Procedures consider the concerns of all those } \\
\text { involved }\end{array}$ \\
\hline & Bias suppression & Procedures are neutral and avoid personal bias \\
\hline & Accuracy & Procedures are based on accurate information \\
\hline & Correctability & Procedures are corrected when identified as wrong \\
\hline & Ethicality & Procedures uphold ethical and moral values \\
\hline \multirow{2}{*}{$\begin{array}{l}\text { Interpersonal (Bies \& Moag, } \\
\text { 1986; Greenberg, 1993) }\end{array}$} & Respect & Procedures are implemented sincerely and politely \\
\hline & Propriety & $\begin{array}{l}\text { Procedures are implemented refraining from } \\
\text { improper remarks }\end{array}$ \\
\hline Informational (Bies \& Moag, & Truthfulness & Procedures are explained honestly \\
\hline 1986; Greenberg, 1993) & Justification & Procedures are explained adequately \\
\hline
\end{tabular}


Table 4 Classroom Assessment Fairness Conceptualization

\begin{tabular}{|c|c|c|}
\hline Dimensions of CA fairness & Justice principles & Descriptions \\
\hline \multirow[t]{3}{*}{ 1. Classroom Distributive Justice } & 1.1. Equity & $\begin{array}{l}\text { Congruence between students' contribution and their actual } \\
\text { outcome }\end{array}$ \\
\hline & 1.2. Equality & Distribution of classroom outcomes equally \\
\hline & 1.3. Need & Considering students' needs when distributing outcomes \\
\hline \multirow[t]{8}{*}{ 2. Classroom Procedural Justice } & 2.1. Consistency & Consistent application of classroom procedures \\
\hline & 2.2. Accuracy & $\begin{array}{l}\text { Accurate application of classroom procedures based on } \\
\text { sufficient data }\end{array}$ \\
\hline & 2.3. Bias Suppression & $\begin{array}{l}\text { Classroom procedures are not biased due to students' gender, } \\
\text { cultural background, and other issues }\end{array}$ \\
\hline & 2.4. Correctability & $\begin{array}{l}\text { Teacher correct their classroom procedures when identified as } \\
\text { wrong }\end{array}$ \\
\hline & 2.5. Ethicality & The classroom procedure upholds ethical standards \\
\hline & 2.6. Voice & $\begin{array}{l}\text { Teacher gives voice to students to appeal for their classroom } \\
\text { procedures }\end{array}$ \\
\hline & 2.7. Transparency & $\begin{array}{l}\text { Teacher enact classroom procedures clearly and with } \\
\text { transparency }\end{array}$ \\
\hline & 2.8. Reasonableness & Teachers enact their classroom procedures reasonably \\
\hline \multirow{4}{*}{ 3. Classroom Interactional Justice } & 3.1. Respect & Teacher communicates students' outcomes with respect \\
\hline & 3.2. Caring & $\begin{array}{l}\text { Teacher shows kindness, concern, sensitivity for students and } \\
\text { their rights }\end{array}$ \\
\hline & $\begin{array}{l}\text { 3.3. Adequate, Truthful, } \\
\text { and Justified Information }\end{array}$ & Teacher provides logical, truthful, and adequate feedback \\
\hline & 3.4. Timeliness & $\begin{array}{l}\text { Teacher communicates his/her feedback and information } \\
\text { timely }\end{array}$ \\
\hline
\end{tabular}

